\title{
Bioremediation potential of filamentous fungi in methylene blue: Solid and liquid culture media
}

\section{Potencial de biorremediação de fungos filamentoso em azul de metileno: Meio sólido e líquido}

\author{
Geovania dos Santos Menezes', Tamíris Aparecida de Carvalho', Wandson dos Santos Almeida1, \\ Eliana Midori Sussuchi', Pedro Roberto Almeida Viégas ${ }^{1}$, Regina Helena Marino ${ }^{1 *}$
}

\author{
'Universidade Federal de Sergipe/UFS, Departamento de Engenharia Agronômica, São Cristóvão, SE, Brasil \\ *Corresponding author: rehmarino@hotmail.com \\ Received in February 11, 2017 and approved in July 24, 2017
}

\begin{abstract}
The evaluation of the bioremediation potential of microbial with dyes in solid and liquid culture media has been described, but prior studies have not mentioned which culture method is most appropriate for selection of microorganisms. Therefore, the aim of this work was to evaluate the bioremediation potential of filamentous fungi in liquid and solid culture media with methylene blue. The fungi isolates tested were Pleurotus ostreatoroseus (POR-SP1, POR-SP2), P. ostreatus (DF39, EF58 and EF60), Pycnoporus sanguineus (PS) and Fusidium sp. (FUS). The methylene blue concentrations tested were $0,5,10$, and $50 \mathrm{mg} \mathrm{L}^{-1}$ in the solid medium and 0, 5, 25, 50, and 100 mg L-1 in the liquid medium. In the solid medium, the mycelial diameters of DF39, EF58, FUS, and PS were not influenced by the increase in dye concentration. In the liquid medium, DF39, EF58, EF60, and FUS showed a constant methylene blue degradation rate with increasing dye concentration. The dye degradation rate was correlated with the $\mathrm{pH}$ of the liquid medium for EF58, EF60, and FUS. The lower diameter growth in the solid medium did not influence the methylene blue dye degradation rate in the liquid medium.
\end{abstract}

Index terms: Environmental microbiology; biodegradation; dye.

\section{RESUMO}

A avaliação do potencial biorremediador microbiano com corantes é descrita em meio de cultura sólido e líquido, mas não é mencionado qual método de cultivo é o mais apropriado na seleção de microrganismos. Para tanto, o objetivo deste trabalho foi avaliar o potencial de biorremediação de fungos filamentosos, em meios de cultura líquido e sólido com azul de metileno. Os isolados fúngicos testados foram: Pleurotus ostreatoroseus (POR-SP1 e POR-SP2), P. ostreatus (DF39, EF58 e EF60), Pycnoporus sanguineus (PS) e Fusidium sp. (FUS).


No meio sólido, o diâmetro micelial de DF39, EF58, FUS e PS não foi influenciado pelo aumento da concentração de corante. Em meio líquido, DF39, EF58, EF60 e FUS apresentaram degradação do azul de metileno constante com o aumento da concentração do corante. A taxa de degradação do corante foi correlacionada com o pH do meio líquido, para EF58, EF60 e FUS. O menor crescimento, em diâmetro, em meio sólido, não influenciou na taxa de degradação do corante azul de metileno, em meio líquido.

Termos para indexação: Microbiologia ambiental; biodegradação; corante.

\section{INTRODUCTION}

The consumption of pesticides and the dumping of chemical residues from industrial and domestic sources have contributed to environmental contamination (soil, air, and water resources) for food, animals, and humans (Soares et al., 2011; Gomes; Barizon, 2014).

According to Guimarães et al. (2010), projections indicate the possibility of a $50 \%$ increase in contaminated areas that require remediation in Europe by 2025. Bioremediation consists of a process that uses microorganisms or plants to break down, neutralize or reduce pollutants in the environment, and it is considered a viable alternative for the treatment of soil and effluents (Moreira; Siqueira, 2006). However, it depends on environmental conditions and the contaminant and microorganism employed (Zhu et al., 2013; Skariyachan et al., 2016).

Among microorganisms, filamentous fungi play an important role in bioremediation due to their metabolic capacity to degrade different toxic and recalcitrant compounds, such as organic pollutants, textile dyes, textile effluents, petroleum, polyaromatic hydrocarbons, plastics, and pesticides (Ferraz, 2004; Deshmukh; Khardenavis; Purohit, 2016).

Among the synthetic dyes, methylene blue is a heterocyclic aromatic compound $\left(\mathrm{C}_{16} \mathrm{H}_{18} \mathrm{CIN}_{3} \mathrm{~S} .3 \mathrm{H}_{2} \mathrm{O}\right)$ used 
in human medicine (Ginimuge; Jyothi, 2010) and fungi (Singh; Vishwakarma; Srivastava, 2013).

The use of dyes for the selection of bioremediation microorganisms is a fast and efficient method. Fungi and bacteria produce oxidative enzymes that are capable of breaking aromatic rings and/or double bonds as well as promoting discoloration, which indicates the biodegradation of the chemical compound, and they contribute to a reduction in environmental pollution (Al-Jawhari, 2015; Sumandono et al., 2015; Kundjadia et al., 2016).

The efficiency of filamentous fungi is due to the ability to adapt their metabolism to different sources of carbon and energy. This metabolic flexibility occurs due to the production of enzymes, such as laccases, that degrade toxic compounds into ammonia to form biomass (Kanagaraj; Senthilvelan; Panda, 2015). However, the bioremediation potential of fungi depends on the species of fungus and the type of substrate (Singh et al., 2011).

The presence of the enzyme laccase is important in bioremediation studies, and this enzyme does not have substrate specificity, which gives it the potential to be used in the degradation of different compounds (Kanagaraj; Senthilvelan; Panda, 2015). This enzyme can be synthesized by filamentous fungi, such as Pleurotus (Kundjadia et al., 2016; Skariyachanet al., 2016), Fusarium (Wu; Nian, 2013), Alternaria, Aspergillus, Cladosporium, Penicillium, and Rhizopus (Monssef; Hassan; Ramadan, 2016), and by bacteria (Sondiet al., 2014, Ausec et al., 2015, Chandra; Chowdhary, 2015).

In the literature, evaluation of the bioremediation potential of fungal and/or bacterial isolates with dyes has been described in solid (Al-Jawhari, 2015) and liquid culture media (Perovano Filho; Silva; López, 2011). However, there has been no mention of which cultivation method is the most appropriate for the selection of fungi isolates. This study aimed to select bioremediation fungi from methylene blue in solid and liquid media.

\section{MATERIAL AND METHODS}

The fungal isolates used were Pleurotus ostreatus (DF39, EF60, and EF58), Pleurotus ostreatoroseus (PORSP1, POR-SP2), Fusidium sp. (FUS), and Pycnoporus sanguineus (PS).

\section{Mycelial growth and discoloration of methylene blue in solid medium}

The experimental design was a completely randomized block in a $7 \times 4$ factorial, namely, seven fungal isolates (DF39, EF60, EF58, POR-SP1, POR-SP2,
FUS, and PS) and four concentrations of dye $(0,10$, and $50 \mathrm{mg} \mathrm{L}^{-1}$ ), in a culture medium based on malt extract agar with four replicates per treatment.

The methylene blue dye used belongs to the brand PROQUÍMIOS, which has the chemical formula $\mathrm{C}_{16} \mathrm{H}_{18} \mathrm{CIN}_{3} \mathrm{~S} .3 \mathrm{H}_{2} \mathrm{O}$ and a molar mass of $373.90 \mathrm{~g} \mathrm{~mol}^{-1}$. The culture medium was based on a malt extract $\left(25 \mathrm{~g} \mathrm{~L}^{-1}\right)$ and agar $\left(20 \mathrm{~g} \mathrm{~L}^{-1}\right)$ and was autoclaved at $120^{\circ} \mathrm{C}$ and $1 \mathrm{~atm}$ for 15 minutes. After cooling to $45-50{ }^{\circ} \mathrm{C}$, the methylene blue dye was added into the culture medium according to the concentration, homogenized and distributed in Petri dishes. In the solidified culture medium, a 6-mm diameter mycelial disc was transferred with the mycelium part placed on the culture medium and incubated at $25 \pm 1{ }^{\circ} \mathrm{C}$ for four days without a photoperiod. During the incubation period, the mycelial diameter was evaluated using two cross-measures of the colony diameter during a 24-hour interval for four days. The percentage of the reduction in diameter $(\mathrm{RD})$ was obtained via the formula, where DM50 = mean diameter at a concentration of $50 \mathrm{mg} \mathrm{L}^{-1}$, and $\mathrm{DM} 0=$ mean mycelial diameter at a concentration of $0 \mathrm{mg} \mathrm{L}^{-1}$ (control).

\section{Discoloration of methylene blue by the filamentous fungi in the liquid medium}

The experimental design included completely randomized blocks in a $7 \times 5$ factorial, namely, seven fungal isolates (DF39, EF60, EF58, POR-SP1, POR-SP2, FUS, and PS) and five concentrations of dye ( $0,25,50$ and $100 \mathrm{mg} \mathrm{L}^{-1}$ ), using a culture based on malt extract with four replicates per treatment.

The bioassay was run in test tubes containing $10 \mathrm{~mL}$ of malt extract-based culture medium that was supplemented with the methylene blue dye according to concentration. The culture medium-dye test tubes were autoclaved at $120^{\circ} \mathrm{C}$ for 10 minutes. After cooling, an inoculating disc containing the $1 \mathrm{~cm}$ diameter mycelium was transferred by test tube into an aseptic chamber and incubated at $25 \pm 1{ }^{\circ} \mathrm{C}$ without a photoperiod.

The parameters evaluated were final concentration of the methylene blue, percentage of dye degradation, and $\mathrm{pH}$ of the culture medium after 19 days of cultivation. Absorption spectra were collected using a Varian CARY100 UV-VIS spectrophotometer to determine the standard curve of methylene blue using concentrations of $0,5,25$, 50 , and $100 \mathrm{mg} \mathrm{L}^{-1}$ for the dye by culture medium without the presence of the fungus. The maximum absorption values of the dye were obtained at a wavelength of $666 \mathrm{~nm}$. The equation of the line for determining the concentration of methylene blue was $\mathrm{y}=0.09875+011646 \mathrm{x}, \mathrm{R}^{2}=$ 0.9947 , where $\mathrm{y}=$ absorbance and $\mathrm{x}=$ concentration of the dye $\left(\mathrm{mg} \mathrm{L}^{-1}\right)$. The percentage of dye degradation 
(DC) was determined via $\mathrm{DC}(\%)=[(\mathrm{AC}-\mathrm{AF}) / \mathrm{AC}] \mathrm{x}$ 100 , where $\mathrm{AC}=$ absorbance of the culture medium in the control treatment (without fungi) and $\mathrm{AF}=$ absorbance of the culture medium with the fungi according to the methodology of Ma et al. (2014).

\section{Statistical analysis}

The results were submitted to Analysis of Variance (ANOVA), and in cases where there was a significant difference, the Scott-Knott test was applied at a 5\% significance level for comparison of the means using the Assistat program.

\section{RESULTS AND DISCUSSION}

\section{Mycelial growth and discoloration of methylene blue in the solid medium}

For the Pleurotus ostreatus (DF39 and EF58), Fusidium sp. (FUS), and Pycnoporus sanguineus (PS) isolates, an increase in the concentration from 0 to $50 \mathrm{mg}$ $\mathrm{L}^{-1}$ for methylene blue did not influence the mean mycelial diameter. The mycelial growth was adjusted to the linear regression model for EF58 and to the polynomial for Fusidium sp.; however, for DF39 and PS, the mycelial growth was not adjusted to any regression model (Table 1).

The mycelial diameters of DF39, EF58, FUS, and PS exhibited a reduction of 7.6 to $22.2 \%$ without differences between the isolates at a concentration of 50 $\mathrm{mg} \mathrm{L}^{-1}$ of dye in relation to the control $\left(0 \mathrm{mg} \mathrm{L}^{-1}\right)$; however, it was significantly lower than the other isolates tested (Table 1). Isolates DF39, EF58, FUS, and PS promoted the discoloration of the medium, which may characterize the degradation of the dye according to Ferreira-Leitão, Silva and Bon (2003). They reported that the lignin peroxidase oxidizes the methylene blue and can promote the discoloration of the dye in the culture medium due to cleavage of the aromatic ring. E Abo-State et al. (2011) also associate the process of discoloration of the culture medium with methylene blue by the action of the laccase enzyme, which belongs to peroxidase and is commonly synthesized by white rot fungi. The degradation of dyes by fungi, such as Pleurotus ostreatus, P. Florida, and P. sapidus, was quantified by Kundjadia et al. (2016), who observed the discoloration of 88 to $98 \%$ of the dye. In this present study, it was not possible to quantify the percentage of degradation of the dye in the solid medium, although discoloration of the culture medium was observed with isolates DF39, EF58, FUS, and PS, indicating the degradation of the dye.

Barrasa et al. (2014) observed that there are two patterns of discoloration of synthetic dyes in solid culture medium. According to these authors, saprophytic white rot fungi, belonging to the order Agaricales, form a brown halo external to the colony due to the increases synthesis of peroxidase enzymes and laccases on the colony edges. For white wood rot fungi, the degradation of the dye occurred in the internal region, where the intense activity of lignocellulosic enzymes can which results in the formation of a brown circle inside the colony, as observed with PORSP1. For other isolates tested, the formation of internal and external brown circles in the colony was not observed.

Zhang et al. (2015) mentioned that the potential bioremediation of Pycnoporus sanguineus occurs due to the action of laccase enzymes, which contributed to the transformation and degradation of anthracene. The dye degradation process can provide carbon and energy sources to the bioremediation fungi and thus positively influenced their growth, depending on the ability of the fungi to

Table 1: Mycelial diameter and percentage reduction of mycelial diameter (RD) of the filamentous fungi isolates grown in culture medium with methylene blue after 4 days.

\begin{tabular}{|c|c|c|c|c|c|c|}
\hline \multirow{2}{*}{ Fungi } & \multicolumn{4}{|c|}{ Mycelial diameter $(\mathrm{cm})$ for concentration of dye $\left(\mathrm{mg} \mathrm{L}^{-1}\right)$} & \multirow{2}{*}{$\begin{array}{l}\text { RD } \\
(\%) \\
\end{array}$} & \multirow{2}{*}{$\mathrm{R}^{2}$} \\
\hline & 0 & 5 & 10 & 50 & & \\
\hline DF39 & $2.2 \mathrm{bA}^{1}$ & $2.1 \mathrm{bA}$ & $2.5 \mathrm{bA}$ & $2.0 \mathrm{bA}$ & $7.6 \mathrm{~d}$ & $\mathrm{R}^{2}=0.70 \mathrm{~ns}^{2}$ \\
\hline EF58 & $4.2 \mathrm{aA}$ & $3.6 \mathrm{aA}$ & $4.0 \mathrm{aA}$ & $3.4 \mathrm{aA}$ & $17.9 \mathrm{~d}$ & $\mathrm{R}^{2}=0.59$ * \\
\hline EF60 & $4.0 \mathrm{aA}$ & $3.4 \mathrm{aA}$ & $3.6 \mathrm{aA}$ & $2.5 \mathrm{aB}$ & $38.5 \mathrm{c}$ & $\mathrm{R}^{2}=0.92 * *$ \\
\hline POR-SP1 & $3.8 \mathrm{aA}$ & $3.8 \mathrm{aA}$ & $2.7 \mathrm{bB}$ & $0.9 \mathrm{bC}$ & $76.2 \mathrm{a}$ & $\mathrm{R}^{2}=0.95 * *$ \\
\hline POR-SP2 & $3.9 \mathrm{aA}$ & $4.1 \mathrm{aA}$ & $2.4 \mathrm{bB}$ & $1.6 \mathrm{bB}$ & $60.7 \mathrm{~b}$ & $\mathrm{R}^{2}=0.73 * *$ \\
\hline FUS & $3.8 \mathrm{aA}$ & $3.3 \mathrm{aA}$ & $3.7 \mathrm{aA}$ & $3.2 \mathrm{aA}$ & $14.3 \mathrm{~d}$ & $\mathrm{R}^{2}=0.48 * *$ \\
\hline PS & $2.4 \mathrm{bA}$ & $2.3 \mathrm{bA}$ & $2.1 \mathrm{bA}$ & $1.9 \mathrm{bA}$ & $22.2 \mathrm{~d}$ & $\mathrm{R}^{2}=0.83 \mathrm{~ns}$ \\
\hline
\end{tabular}

${ }^{1}$ Media followed by the same lowercase (in the column) and uppercase (in the line) letter did not differ according to Scott-Knott's test at a $5 \%$ probability; ${ }^{2}$ ns is not significant, * is significant at $1 \%(p<0.1)$, and ** is significant at $5 \%(0.01 \leq p<0.05)$. 
synthesize specific enzymes on the culture medium (Barrasa et al., 2014; Kanagaraj; Senthilvelan; Panda, 2015).

For the P. ostreatus EF60 isolate, the increase in the methylene blue concentration reduced the mycelial diameter at $50 \mathrm{mg} \mathrm{L}^{-1}$ by $38.5 \%$, and the mycelial growth was adjusted to a quadratic regression model. The mycelial diameter was reduced $76.2 \%$ for POR-SP1 in $10 \mathrm{mg} \mathrm{L}^{-1}$ methylene blue concentration and $60.7 \%$ for POR-SP2 at a dye concentration of $50 \mathrm{mg} \mathrm{L}^{-1}$. For these isolates, the mycelial diameter with increased methylene blue dye concentration was adjusted to a linear regression (Table 1); however, there was no discoloration in the methylene blue dye as observed with isolates DF39, EF58, FUS, and PS.

Sumandono et al. (2015) also observed a reduction in mycelial growth of fungi of white rot Phanerochaete crysosporium with concentrations from 500 to $1500 \mathrm{ppm}$ of the RBBR dye. According to these authors, this result is due to the toxic effect of the concentration of the dye on the microbial metabolism, which may have occurred with isolates POR-SP1 and POR-SP2 of P. ostreatoroseus and EF60 of P. ostreatus, which are also fungi of white rot.

Considering the $50 \mathrm{mg} \mathrm{L}^{-1}$ concentration, isolates EF58, EF60, and FUS presented 2.5 to $3.4 \mathrm{~cm}$ mycelial diameters without differences among the isolates, and these were significantly higher than those for DF39, PORSP1, POR-SP2, and PS, which presented 0.9 to $2.0 \mathrm{~cm}$ diameters (Table 1).

The lowest growth in diameter for the DF39 isolate was observed at the $50 \mathrm{mg} \mathrm{L}^{-1}$ concentration for the dye. This does not represent the lowest potential bioremediator since this isolate presented steady growth with less reduction in growth as a result of the increase in the dye concentration and the discoloration, indicating degradation of the chemical compound according to Kundjadia et al. (2016). Isolates DF39, EF58, FUS and PS have the potential to degrade the dye, even with a smaller diameter for the mycelial growth, as observed with the DF39 isolate in the solid medium.

\section{Discoloration of methylene blue by filamentous fungi in the liquid medium}

The use of all fungi isolates significantly reduced the concentration of dye with no difference among the isolates tested up to the $50 \mathrm{mg} \mathrm{L}^{-1}$ concentration. For the treatment with $100 \mathrm{mg} \mathrm{L}^{-1}$ of dye, isolate P. ostretatus EF60 showed the lowest concentration of dye compared with the other ones. All isolates presented a reduction in dye concentration, which was adjusted to the quadratic regression with the dye increasing in the liquid medium from 5 to $100 \mathrm{mg} \mathrm{L}^{-1}$ (Table 2).
For the degradation of the dye, it occurred at the concentration of $5 \mathrm{mg} \mathrm{L}^{-1}$; isolates DF39, FUS, and PS resulted in greater degradation of the dye. At a concentration of $25 \mathrm{mg} \mathrm{L}^{-1}$ of methylene blue dye, isolates POR-SP2, FUS, and PS showed the highest dye degradation. For $\mathrm{E}$ at $50 \mathrm{mg} \mathrm{L}^{-1}$, the degradation of the dye was $53.3 \%$ on average, without a significant difference between the isolates. At a concentration of $100 \mathrm{mg} \mathrm{L}^{-1}$, isolates DF39, EF60, POR-SP2, and FUS showed 46.9\%, $54.1 \%, 46.6 \%$, and $47.3 \%$ degradation, respectively, and these values were significantly higher than those for the other isolates tested. The degradation of the dye in the culture medium was adjusted to the quadratic regression model with increasing concentration of the dye in all isolates tested (Table 2).

For isolates DF39, EF58, EF60, and FUS, the increase in the concentration did not inhibit the degradation of the methylene blue dye because there was no difference in the degradation for the dye concentrations between 25 and $100 \mathrm{mg} \mathrm{L}^{-1}$. However, increasing the concentration from 5 to $25 \mathrm{mg} \mathrm{L}^{-1}$ significantly stimulated discoloration and degradation of it in all isolates tested (Table 2).

The increase in the degradation with concentration from 5 to $25 \mathrm{mg} \mathrm{L}^{-1}$ for the dye may be due to the use of the chemical as the source of carbon, nitrogen and/ or energy (Ferraz, 2004). Kanagaraj, Senthilvelan and Panda (2015) reported that dyes, when degraded by bioremediation fungi, release ammonia, which is rapidly immobilized by microbial biomass and ensures mycelial growth, discoloration and dye degradation (Kundjadia et al., 2016).

The cultures of the DF39 isolate for increasing doses of dye did not influence the $\mathrm{pH}$ of the culture medium in relation to the negative control, except for the $100 \mathrm{mg} \mathrm{L}^{-1}$ concentration in which it was significantly higher than the control. For this isolate, the $\mathrm{pH}$ of the culture medium as a function of the dye concentration was adjusted to the linear regression model, as was also observed for the EF58 isolate. For EF58 and EF60, the increase in the concentration from 50 to $100 \mathrm{mg} \mathrm{L}^{-1}$ resulted in an increase in $\mathrm{pH}$ in relation to the negative control (Table 3). For the treatments with POR-SP1, POR-SP2, and PS, the $\mathrm{pH}$ increase was only observed for the $100 \mathrm{mg} \mathrm{L}^{-1}$ concentration compared with the negative control. The $\mathrm{pH}$ variation as a function of the dye concentration in the culture medium was adjusted to the quadratic regression model when isolates EF60, POR-SP1, POR-SP2, FUS, and PS were grown (Table 3).

Sumandono et al. (2015) reported that the degradation of the RBBR dye occurred at $\mathrm{pH} 4.0$ by the fungi of white rot, which was associated with the enzymes 
laccase and manganese peroxidase. Monssef, Hassan and Ramadan (2016) observed that the optimal $\mathrm{pH}$ for the laccase was 5.0, but Zhu et al. (2013) mentioned that the best laccase activity occurs at $60^{\circ} \mathrm{C}$ and $\mathrm{pH} 2.2$. However, $\mathrm{Wu}$ and Nian (2013) observed that a $\mathrm{pH}$ of 6.5 and $20^{\circ} \mathrm{C}$ favored laccase activity. Tian et al. (2012) cited that laccase activity influenced the $\mathrm{pH}$ of the medium. However, Kundjadia et al. (2016) reported that the $\mathrm{pH}$ did not interfere with the discoloration and degradation of the dye by Pleurotus isolates in liquid medium, and this result could be associated with the presence of other oxidative enzymes and/or specific fungi isolates.

In a preliminary test, it was observed that the addition of hydrochloric acid reduced the $\mathrm{pH}$ of the medium but did not change the coloring of the dye. Thus, the discoloration and degradation of the dye observed in this work is probably due to the action of oxidative enzymes, such as laccases, as reported by Abo-State et al. (2011).

The degradation of methylene blue was correlated with the $\mathrm{pH}$ of the culture medium of isolates EF58, EF60, and FUS. However, there was no correlation between the degradation and $\mathrm{pH} /$ mean diameter when we used the DF39 and PS isolates. In contrast, for the treatment with isolates POR-SP1 and POR-SP2, mycelial growth in the solid medium was negatively correlated with the degradation in the liquid medium, i.e., the smaller mycelial diameter contributed to increased dye degradation. However, isolates DF39, EF58, EF60, FUS, and PS presented a lower reduction in the mycelial diameter with an increase in the methylene blue concentration in the solid medium and showed no correlation with the degradation in the liquid medium (Table 4).

The use of selection criteria for bioremediation fungi only for mycelial growth in solid culture medium does not allow an accurate result since there is no positive correlation between the mycelial diameter and the percentage of degradation (Table 4).

In general, isolates DF39, EF60, POR-SP2, and FUS can be selected as bioremediators because they did not show a decrease in degradation from 25 to $100 \mathrm{mg} \mathrm{L}^{-1}$ of methylene blue dye. However, the bioremediator action of a fungi isolate depends on the dye (Al-Jawhari, 2015) and enzyme-specific synthesis (Barrasa et al., 2014).

Table 2: Percentage of the concentration and degradation of methylene blue dye present in the liquid culture medium after 19 days of growth.

\begin{tabular}{|c|c|c|c|c|c|}
\hline \multirow{2}{*}{ Fungi } & \multicolumn{4}{|c|}{ Dye concentration in the medium (\%) } & \multirow{2}{*}{$\mathrm{R}^{2}$} \\
\hline & $5 \mathrm{mg} \mathrm{L}^{-1}$ & $25 \mathrm{mg} \mathrm{L}^{-1}$ & $50 \mathrm{mg} \mathrm{L}^{-1}$ & $100 \mathrm{mg} \mathrm{L}^{-1}$ & \\
\hline DF39 & $3.8 \mathrm{aD}^{1}$ & $12.5 \mathrm{aC}$ & $22.5 \mathrm{aB}$ & $52.8 \mathrm{cA}$ & $\mathrm{R}^{2}=1.00 * * 2$ \\
\hline EF58 & $5.3 \mathrm{aD}$ & $12.6 \mathrm{aC}$ & $24.9 \mathrm{aB}$ & $56.7 \mathrm{bA}$ & $R^{2}=1.00 * \star$ \\
\hline EF60 & $4.3 \mathrm{aD}$ & $12.5 \mathrm{aC}$ & $21.7 \mathrm{aB}$ & $45.4 \mathrm{dA}$ & $\mathrm{R}^{2}=1.00 * *$ \\
\hline POR-SP1 & $4.6 \mathrm{aD}$ & $12.6 \mathrm{aC}$ & $26.3 \mathrm{aB}$ & $62.5 \mathrm{aA}$ & $R^{2}=1.00 * \star$ \\
\hline POR-SP2 & $4.1 \mathrm{aD}$ & $10.5 \mathrm{aC}$ & $20.4 \mathrm{aB}$ & $53.0 \mathrm{cA}$ & $\mathrm{R}^{2}=1.00 * *$ \\
\hline FUS & $3.8 \mathrm{aD}$ & $10.5 \mathrm{aC}$ & $23.2 \mathrm{aB}$ & $52.3 \mathrm{cA}$ & $R^{2}=1.00 * *$ \\
\hline PS & $3.6 \mathrm{aD}$ & $10.3 \mathrm{aC}$ & $21.4 \mathrm{aB}$ & $57.3 \mathrm{bA}$ & $\mathrm{R}^{2}=1.00 * *$ \\
\hline \multirow{2}{*}{ Fungi } & \multicolumn{4}{|c|}{ Degradation of the dye (\%) } & \multirow{2}{*}{$\mathrm{R}^{2}$} \\
\hline & $5 \mathrm{mg} \mathrm{L}^{-1}$ & $25 \mathrm{mg} \mathrm{L}^{-1}$ & $50 \mathrm{mg} \mathrm{L}^{-1}$ & $100 \mathrm{mg} \mathrm{L}^{-1}$ & \\
\hline DF39 & $21.2 \mathrm{aB}$ & $48.5 \mathrm{bA}$ & $54.1 \mathrm{aA}$ & $46.9 \mathrm{aA}$ & $\mathrm{R}^{2}=0.94 * *$ \\
\hline EF58 & $-5.9 \mathrm{DB}$ & $47.9 \mathrm{bA}$ & $49.4 \mathrm{aA}$ & $42.9 \mathrm{bA}$ & $\mathrm{R}^{2}=0.86 * *$ \\
\hline EF60 & 12.6 bB & 48.6 bA & $55.6 \mathrm{aA}$ & $54.1 \mathrm{aA}$ & $\mathrm{R}^{2}=0.93 * *$ \\
\hline POR-SP1 & $6.5 \mathrm{cA}$ & $48.1 \mathrm{bA}$ & $46.6 \mathrm{aA}$ & 37.2 bB & $\mathrm{R}^{2}=0.82 * *$ \\
\hline POR-SP2 & 15.9 bC & $56.1 \mathrm{aA}$ & $58.2 \mathrm{aA}$ & $46.6 \mathrm{aB}$ & $\mathrm{R}^{2}=0.88 * *$ \\
\hline FUS & 20.9 aB & $56.2 \mathrm{aA}$ & $52.8 \mathrm{aA}$ & $47.3 \mathrm{aA}$ & $\mathrm{R}^{2}=0.78 * *$ \\
\hline PS & $24.0 \mathrm{aC}$ & $57.1 \mathrm{aA}$ & $56.2 \mathrm{aA}$ & $42.4 \mathrm{bB}$ & $\mathrm{R}^{2}=0.85^{\star *}$ \\
\hline
\end{tabular}

${ }^{1}$ Media followed by the same lowercase (in the column) and uppercase (in the line) letter did not differ according to Scott-Knott's test at a $5 \%$ probability; ${ }^{2}$ ns is not significant, * is significant at $1 \%(p<0.1)$ and $* *$ is significant at $5 \%(0.01 \leq p<0.05)$. 
Table 3: Average $\mathrm{pH}$ of the culture medium based on the malt extract with methylene blue dye after culturing with fungi for 19 days.

\begin{tabular}{ccccccc}
\hline \multirow{2}{*}{ Fungi } & \multicolumn{5}{c}{$\mathrm{pH}$ as a function of concentration of dye $\left(\mathrm{mg} \mathrm{\textrm {L } ^ { - 1 }}\right)$} & \multirow{2}{*}{$\mathrm{R}^{2}$} \\
\cline { 2 - 5 } & 0 & 5 & 25 & 50 & 100 & \\
\hline Negative control & $5.5 \mathrm{eA}^{1}$ & $5.0 \mathrm{aA}$ & $5.0 \mathrm{aA}$ & $4.9 \mathrm{bA}$ & $4.7 \mathrm{bA}$ & $\mathrm{R}^{2}=0,66 * * 2$ \\
DF39 & $4.9 \mathrm{eA}$ & $4.9 \mathrm{aA}$ & $5.1 \mathrm{aA}$ & $5.3 \mathrm{bA}$ & $5.9 \mathrm{aA}$ & $\mathrm{R}^{2}=0.95 * *$ \\
EF58 & $5.0 \mathrm{eB}$ & $4.6 \mathrm{aB}$ & $5.0 \mathrm{aB}$ & $6.6 \mathrm{aA}$ & $6.1 \mathrm{aA}$ & $\mathrm{R}^{2}=0.62 * *$ \\
EF60 & $7.8 \mathrm{bA}$ & $4.3 \mathrm{bD}$ & $4.8 \mathrm{aD}$ & $6.3 \mathrm{aB}$ & $5.8 \mathrm{aC}$ & $\mathrm{R}^{2}=0.58^{* *}$ \\
POR-SP1 & $6.8 \mathrm{cA}$ & $4.9 \mathrm{aB}$ & $5.5 \mathrm{aB}$ & $5.0 \mathrm{bB}$ & $6.1 \mathrm{aA}$ & $\mathrm{R}^{2}=0.45^{* *}$ \\
POR-SP2 & $6.3 \mathrm{dA}$ & $5.0 \mathrm{aB}$ & $5.1 \mathrm{aB}$ & $4.9 \mathrm{bB}$ & $6.3 \mathrm{aA}$ & $\mathrm{R}^{2}=0.69^{* *}$ \\
FUS & $8.9 \mathrm{aA}$ & $4.0 \mathrm{bC}$ & $4.9 \mathrm{aB}$ & $5.0 \mathrm{bB}$ & $5.5 \mathrm{aB}$ & $\mathrm{R}^{2}=0.50^{* *}$ \\
PS & $5.1 \mathrm{eB}$ & $4.1 \mathrm{bB}$ & $4.9 \mathrm{aB}$ & $4.9 \mathrm{bB}$ & $6.1 \mathrm{aA}$ & $\mathrm{R}^{2}=0.74^{*}$ \\
\hline
\end{tabular}

${ }^{1}$ Media followed by the same lowercase (in the column) and uppercase (in the line) letter did not differ according to Scott-Knott's test at a $5 \%$ probability; ${ }^{2}$ ns is not significant, * is significant at $1 \%(p<0.1)$ and $* *$ is significant at $5 \%(0.01 \leq p<0.05)$.

Table 4: Correlation coefficients ( $r$ ) for the degradation (D), $\mathrm{pH}$ and mean diameter (DM) of filamentous fungi in the culture medium with methylene blue dye.

\begin{tabular}{cccccccc}
\hline \multirow{2}{*}{ Parameters } & \multicolumn{7}{c}{ Correlation coefficient $(r)$, per fungi } \\
\cline { 2 - 8 } & DF39 & EF58 & EF60 & POR-SP1 & POR-SP2 & FUS & PS \\
\hline D x pH & ns & $0.5911^{*}$ & $0.7879 * *$ & ns & ns & $0.7357^{* *}$ & ns \\
D xDM & ns & ns & Ns & $-0.9350 * *$ & $-0.8579 * *$ & $n s$ & ns \\
\hline
\end{tabular}

ns is not significant, * is significant at $1 \%(p<0.1)$ and ** is significant at $5 \%(0.01 \leq p<0.05)$.

\section{CONCLUSIONS}

The selection of filamentous fungi for bioremediation should be performed with a culture of fungal isolates in solid and liquid medium using the criteria of mycelial growth, degradation and discoloration of the culture medium as a function of an increase in dye concentration. Isolates DF39, EF58, FUS and PS of filamentous fungi presented bioremediation potential in the solid medium. In the liquid medium, isolates DF39, EF58, and EF60 from Pleurotus ostreatus and FUS from Fusidium sp. have bioremediation potential because they maintained a constant degradation of methylene blue with increasing dye concentration. The degradation of a dye in liquid culture medium is influenced by $\mathrm{pH}$, i.e., it depends on the fungal isolate, which may be due to the synthesis of specific oxidative enzymes for each fungus.

\section{REFERENCES}

ABO-STATE, M. A. M. et al. Factors affecting laccase production by Pleurotus ostreatus and Pleurotus sajor-caju. World Applied Sciences Journal, 14(11):1607-1619, 2011.
Al-JAWHARI, I. F. H. Decolorization of methylene blue and crystal violet by some filamentous fungi. International Journal of Environmental Bioremediation \& Biodegradation, 3(2):62-65, 2015.

AUSEC, L. et al. Characterization of a novel high-pH-tolerant laccase-like multicopper oxidase and its sequence diversity in Thioalkali vibrio sp. Applied Microbiology and Biotechnology, 99(23):9987-9999, 2015.

BARRASA, J. M. et al. Wood and humus decay strategies by white-rot basidiomycetes correlate with two different dye decoloration and enzyme secretion patterns on agar plates. Fungal Genetics and Biology, 72(1):106114, 2014.

CHANDRA, R.; CHOWDHARY, P. Properties of bacterial laccases and their application in bioremediation of industrial wastes. Environmental Science, 17(2):326342, 2015.

DESHMUKH, R.; KHARDENAVIS, A. A.; PUROHIT, H. J. Diverse metabolic capacities of fungi for bioremediation. Indian Journal of Microbiology, 56(3):247-264, 2016. 
FERRAZ, A. L. Fungos decompositores de materiais lignocelulolíticos. In: ESPOSITO, E.; AZEVEDO, J. L. Fungos: Uma introdução à biologia, bioquímica e biotecnologia. Caxias do Sul: Educs, 2004. p.215-244.

FERREIRA-LEITAO, V. S.; SILVA, J. G.; BON, E. P. S. Methylene blue and azure $B$ oxidation by horseradish peroxidase: $A$ comparative evaluation of class II e class III peroxidases. Applied Catalysis B: Environmental, 42(1):213-221, 2003.

GINIMUGE, P. R.; JYOTHI, S. D. Methylene blue: Revisited. Journal Anesthesiology Clinical Pharmacology, 26(4):517-520, 2010.

GUIMARÃES, B. C. M. et al. Microbial services and their management: Recent progresses in soil bioremediation technology. Applied Soil Ecology, 46(1):157-167, 2010.

GOMES, M. A. F.; BARIZON, R. R. M. Panorama da contaminação ambiental por agrotóxicos e nitrato de origem agrícola no Brasil: Cenário 1992/2011. Jaguariúna, SP: Embrapa Meio Ambiente, 2014. 35p. (Documentos/ Embrapa Meio Ambiente n.98).

KANAGARAJ, J.; SENTHILVELAN, T.; PANDA, R. C. Degradation of azo dyes by laccase: Biological method to reduce pollution load in dye wastewater. Clean Technologies and Environmental Policy, 17(6):1443-1456, 2015.

KUNDJADIA, P. D. et al. Role of ligninolytic enzymes of white rot fungi (Pleurotus spp.) grown with azo dyes. SpringerPlus, 5(1):1487-1490, 2016.

MA, L. et al. Efficient decolorization and detoxification of the sulfonated azo dye reactive orange 16 and simulated textile wastewater containing reactive orange 16 by the white-rot fungus Ganoderma sp. En3 isolated from the forest of Tzuchin Mountain in China. Biochemical Engineering Journal, 82(1):1-9, 2014.

MOREIRA, F. M. S.; SIQUEIRA. J. O. Microbiologia e bioquímica do solo. Lavras: Editora UFLA, 2006. 303p.

MONSSEF, R. A. A. E.; HASSAN, E. A.; RAMADAN, E. M. Production of laccase enzyme for their potential application to decolorize fungal pigments on aging paper and parchment. Annals of Agricultural Sciences, 61(1):145-154, 2016.

PEROVANO FILHO, N.; SILVA, K. F. S.; LÓPEZ, A. M. Q. Ação de micoflora de efluentes agroindustriais sobre diferentes corantes e substratos lignocelulósicos. Acta Scientiarum Biological Sciences, 33(4):427-435, 2011.
SKARIYACHAN, S. et al. Environmetal assessment of the degradation potential of mushroom fruit bodies of Pleurotus ostreatus (Jacq.: Fr.) P. Kummer towards synthetic azo dyes and contaminating effluents collected from textile industries in Karnataka, Indian. Environmental Monitoring and Assessment, 188(2):1-8, 2016.

SINGH, A. D. et al. Enzymes from spent mushroom substrate of Pleurotus sajor-caju for the decolourisation and detoxification of textile dyes. World Journal of Microbiology and Biotechnology, 27(3):535-545, 2011.

SINGH, M. P.; VISHWAKARMA, S. K.; SRIVASTAVA, A. K. Bioremediation of direct blue 14 and extracellular ligninolytic enzyme production by white rot fungi: Pleurotus spp. BioMed Research Internacional, 2013(ID180156):1-4, 2013.

SOARES, I. A. et al. Fungos na biorremediação de áreas degradadas. Arquivos do Instituto Biológico, 78(2):341350, 2011.

SONDHI, S. et al. Purification and characterization of an extracellular, Thermo-Alkali-Stable, metal tolerant laccase from Bacillus tequilensis SN4. Plos One, 9(5): e96951, 2014.

SUMANDONO, T. et al. Decolorization of remazol brilliant blue $\mathrm{R}$ by new isolated white rot fungus collected from tropical rain forest in East Kalimantan and its ligninolytic enzymes activity. Procedia Environmental Sciences, 28(1):45-51, 2015.

TIAN, G. T. et al. Purification and characterization of a novel laccase from the mushroom Pleurotus nebrodensis. Acta Biochimica Polinica, 59(3):407-412, 2012.

WU, Y. R.; NIAN, D. L. Production optimization and molecular structure characterization of a newly isolated novel laccase from Fusarium solani MAS2, an anthracenedegrading fungus. International Biodeterioration \& Biodegradation, 86(C):382-389, 2013.

ZHANG, S. et al. Contrasting characteristics of anthracene and pyrene degradation by wood rot fungus Pycnoporus sanguineus H1. International Biodeterioration \& Biodegradation, 105(5):228-232, 2015.

ZHU, M.J. et al. Purification a laccase exhibiting dye decolorizing ability from an edible mushroom Russula virescens. International Biodeterioration \& Biodegradation, 82(1):33-39, 2013. 